\title{
B-Glucanases from Candida albicans: Purification, Characterization and the Nature of their Attachment to Cell Wall Components
}

\author{
By V. NOTARIO† \\ Sub-Department of Chemical Microbiology, Department of Biochemistry, University of \\ Cambridge, Tennis Court Road, Cambridge CB2 1QW, U.K.
}

(Received 10 April 1981; revised 20 July 1981)

$\beta$-Glucanase activities were found associated with Candida albicans and their culture fluids. Mild acid treatment of the organisms led to rapid inactivation of $\beta$-glucanase activities, the degree of loss increasing with the age of the cultures; the results suggested an extracytoplasmic location of the cell-associated enzymes. Most of the $\beta$-glucanase activities were associated with the cell walls in organisms phenotypically resistant to amphotericin B methyl ester (AME).

Two proteins (I and II) exhibiting $\beta$-glucanase activity were isolated and purified by conventional procedures from cell-free extracts, cell-wall autolysates and culture fluids of $C$. albicans sensitive and phenotypically resistant to AME. The purified enzymes appeared homogeneous on isoelectric focusing, gel electrophoresis and ultracentrifugation, with molecular weights of 150000 (I) and 49000 (II). Both enzymes hydrolysed cell walls purified from AME-sensitive and phenotypically resistant organisms, but showed different substrate specificities and patterns of activity. Enzyme II hydrolysed $(1 \rightarrow 3)$ - $\beta$-glucans by an endolytic mechanism releasing laminaritetraose as the initial product. Glucose was the only product released by enzyme I. The properties of the individual enzymes were unaffected by their localization or the age of the culture of the organisms.

The loosening of the polysaccharide packing by ultrasonic treatment of cell walls purified from AME-resistant organisms increased the $\beta$-glucanase activities bound to the walls, but did not solubilize them. Autolysis of cell walls released 58 to $66 \%$ of their $\beta$-glucanase activity in $20 \mathrm{~h}$, but no further release was attained on prolonged incubation. The amount of $\beta$-glucanase activity released by autolysis was increased by a variety of pretreatments. Diethyl pyrocarbonate inhibited $\beta$-glucanase activity and prevented autolysis. Evidence is presented indicating that interactions with lipids, polysaccharides and other cell wall proteins may be involved in the control of the activity of the cell wall-associated $\beta$-glucanases in organisms phenotypically resistant to AME.

\section{INTRODUCTION}

A disequilibrium between the synthesis of the cell-wall $\beta$-glucan and its breakdown by endogenous $\beta$-glucanases seems to underlie the onset and development of phenotypic resistance to amphotericin B methyl ester (AME) in Candida albicans. In resistant organisms (cultures in the stationary phase of growth) most of the $\beta$-glucanase activity was found in a latent form bound to the cell wall, and could be activated by a number of treatments (SH-reducing agents, partial enzymic digestion of the walls, reduced aeration of the cultures) which simultaneously decreased the resistance of the organisms to the antibiotic. Other

† Present address: Laboratory of Cellular and Molecular Biology, National Cancer Institute, N.I.H., Bethesda, MD 20205, U.S.A. 
treatments (SH-binding agents, acidic $\mathrm{pH}$, increased aeration) which enhanced resistance of AME-sensitive organisms (cultures in the exponential phase of growth) also diminished $\beta$-glucanase activities (Notario et al., 1982).

The appearance of phenotypic resistance to AME in C. albicans after the cessation of growth was first described by Gale (1974), its cause being ascribed to changes in the cell wall structure and/or composition, since protoplasts prepared from either exponentially-growing or stationary phase organisms were equally sensitive to the antibiotic. The involvement of the cell wall was also supported by the decline in AME resistance promoted by treating late-exponential phase organisms with a variety of exogenous and endogenous cell-wall lytic enzymes (Gale et al., 1975, 1980).

The microbial cell wall, apart from conferring on organisms their characteristic shape and providing protection against environmental changes, is a dynamic structure which undergoes significant alterations during morphogenetic processes (budding, conjugation, sporulation). A glucan component, containing mainly $(1 \rightarrow 3)$ - and some $(1 \rightarrow 6)-\beta$-D-linkages, is responsible for the rigidity and strength of yeast cell walls (Phaff, 1971). Yeasts produce $(1 \rightarrow 3)$ $\beta$-D-glucanases (Villanueva et al., 1976) which can be considered as the main cell-wall plasticizing agents. While there is no conclusive experimental evidence to prove their morphogenetic function, it has been proposed that the state of the cell wall at any given moment of the cell division cycle results from the balance between the activities of $\beta$-glucan-synthetic and -hydrolytic enzymes (Johnson, 1968).

Cell-free extracts (Notario et al., 1976) and culture fluids (Villa et al., 1976) of yeast contain $(1 \rightarrow 3)$ - $\beta$-D-glucanases. Their localization in cytoplasmic vesicles (Cortat et al., 1972), and their dilution once exported to the culture medium, would prevent their attack on the organism responsible for their production. However both $(1 \rightarrow 3)$ - and $(1 \rightarrow 6)$ $\beta$-D-glucanases are also found tightly bound to the cell walls, and are responsible for their autolysis (Fleet \& Phaff, 1974) when incubated under appropriate conditions. To avoid self-destruction, the organisms must have systems to control the activity of the cell wall-associated lytic enzymes, particularly when they are no longer required for active growth. Farkas et al. (1973) proposed the trapping of $\beta$-glucanases by the cell walls, and their subsequent conversion to a latent state, as one possible self-protecting mechanism. Polacheck \& Rosenberger (1978) obtained evidence for a lipid-mediated attachment of autolysins to Aspergillus nidulans hyphal walls, and Dickerson \& Baker (1979) described the association of exo-( $1 \rightarrow 3)$ - $\beta$-D-glucanase with fungal $\beta$-glucans. The mechanism of control of the activity of cell wall lytic enzymes could be directly involved in the development of resistance to AME in C. albicans.

Experiments to establish the possible mechanism(s) which convert the glucan-degrading enzymes to a latent state in AME-resistant organisms, as well as the isolation, purification and characterization of those enzymes from both AME-sensitive and resistant organisms, are described in the present paper.

\section{METHODS}

Organism and culture conditions. Candida albicans strain 6406 was obtained, maintained and cultured as described by Gale (1974) on yeast nitrogen base (Difco; $6.7 \mathrm{~g} \mathrm{l}^{-1}$ ) supplemented with $1 \%(\mathrm{w} / \mathrm{v}$ ) glucose.

Preparation of crude extracts. These were prepared at different stages of growth from intact cells, cell walls and culture fluids. All operations were carried out at $4{ }^{\circ} \mathrm{C}$. (a) Cell-free extracts were prepared from batches of $20 \mathrm{~g}$ dry wt of cells as described by Notario et al. (1982). Dry weight was estimated by measuring the $A_{600}$ of the cultures and referring the data to a standard curve. $(b)$ Cell-wall autolysates were prepared from cell walls purified as described by Notario et al. (1982). The cell walls were suspended ( $25 \mathrm{mg}$ dry wt $\left.\mathrm{ml}^{-1}\right)$ in $50 \mathrm{~mm}$-sodium acetate buffer $\mathrm{pH} 5.5$ containing $0.02 \%(\mathrm{w} / \mathrm{v})$ sodium azide and $1 \mathrm{M}-\mathrm{KCl}$, and incubated at $30^{\circ} \mathrm{C}$ for $4 \mathrm{~h}$. The cell walls were collected by centrifugation at $2000 \mathrm{~g}$ for $5 \mathrm{~min}$, and resuspended in the same volume of the above buffer. The process was repeated at $4 \mathrm{~h}$ intervals for up to $48 \mathrm{~h}$, and all the supernatants were combined. Alternatively, the cell wall suspensions were placed in dialysis bags and dialysed at $30^{\circ} \mathrm{C}$ against $2150 \mathrm{~mm}$-sodium acetate buffer 
pH 5.5 containing $0.02 \%$ sodium azide (without $\mathrm{KCl}$ ) for up to $48 \mathrm{~h}$, changing the buffer every $4 \mathrm{~h}$. Glucose, detergents, urea, guanidine hydrochloride, salts and chaotropic agents were added to the buffer in experiments on the attachment of the $\beta$-glucanases to cell wall components. (c) Culture fluid extracts were prepared from 201 quantities of culture supernatants as described by Villa et al. (1976).

Adsorption on DEAE-Sephadex A-50. All the crude enzyme preparations were dialysed against 8 to 10 volumes of $50 \mathrm{mM}$-sodium acetate buffer $\mathrm{pH} 5.5$ for $24 \mathrm{~h}$, changing the buffer every $3 \mathrm{~h}$, and concentrated either against polyethylene glycol flakes or by ultrafiltration through UM-10 Amicon membranes (in the case of culture fluid extracts). The final volume was adjusted to $250 \mathrm{ml}$ in every case and the pH to 7.5 with Sigma 7-9 Biochemical Buffer. Enzyme adsorption on DEAE-Sephadex A-50 $(10 \mathrm{~g}$ per $250 \mathrm{ml}$ of enzyme extract $)$ was then carried out as described by Notario et al. (1976). The adsorbed material was eluted by resuspending the gel in $100 \mathrm{ml} 2 \mathrm{M}-\mathrm{NaCl}$; the eluate was then dialysed for $48 \mathrm{~h}$ against 10 volumes of $50 \mathrm{~mm}$-sodium acetate buffer pH 5.5 and concentrated against polyethylene glycol to about 3 to $5 \mathrm{ml}$.

Gel filtration. Filtrations were performed on columns of Bio-gel P-150 $(3 \times 50 \mathrm{~cm})$, P-200 $(2 \times 60 \mathrm{~cm})$ and P-300 $(2 \times 60 \mathrm{~cm})$ previously equilibrated with $50 \mathrm{mM}$-sodium acetate buffer $\mathrm{pH} 5 \cdot 5$, eluting the samples with the same buffer. Catalase (mol. wt 24000), aldolase (158000), $\beta$-galactosidase (130000), bovine serum albumin $(67000)$ and ovalbumin (45000) were used to calibrate the Bio-gel P-200 column for molecular weight determinations. Concanavalin A-Sepharose 4B filtrations were carried out on columns $(1 \times 10 \mathrm{~cm})$ previously equilibrated with $0.1 \mathrm{M}$-Tris/maleate buffer $\mathrm{pH} 6.8$ and then with $0.36 \mathrm{M}$-methyl- $\alpha$-D-mannoside in this buffer. In all cases samples were eluted at a flow rate of $30 \mathrm{ml} \mathrm{h}^{-1}$, and $5 \mathrm{ml}$ fractions were collected. The protein content of the fractions was estimated by measuring the $A_{280}$.

Enzyme location by acid treatment of Candida albicans. Organisms were washed twice with water, resuspended in $0.1 \mathrm{M}-\mathrm{HCl}\left(10 \mathrm{mg}\right.$ dry wt ml $\left.{ }^{-1}\right)$ and kept at room temperature for $1 \mathrm{~h}$. After five washings with $50 \mathrm{mM}$-sodium acetate buffer $\mathrm{pH} 5.5$, the cells were mechanically homogenized (Notario et al., 1976) and the enzyme activities were measured in the cell-free extracts prepared as described above. Untreated organisms were used as control. Cell viability and $\alpha$-glucosidase were determined as described by Villanueva \& Gacto (1973).

Enzyme characterization. Isoelectric focusing, polyacrylamide disc electrophoresis and ultracentrifugation experiments were performed as described by Notario et al. (1976). Cross-linked albumin (giving four bands, of mol. wt $66000,132000,198000$ and 264000 , in the presence of SDS) was used as standard for molecular weight determinations in polyacrylamide gel electrophoresis. Gels were stained for glycoproteins as described by Racusen (1979). Yeast alcohol dehydrogenase $\left(s_{20, w} 7.3 \mathrm{~S}\right)$, L-amino acid oxidase (4.7S), aldolase (7.55S) and $\beta$-galactosidase $(6.6 \mathrm{~S})$ were used as reference to determine the sedimentation coefficients and molecular weights of the purified enzymes in ultracentrifugation experiments.

The effect of $\mathrm{pH}$ and temperature on the catalytic activity and denaturation of the enzymes, their kinetic properties and specificity, and the influence of a variety of effectors were studied as described by Notario et al. $(1976,1979)$.

Chemical analysis of purified enzymes. Enzyme samples recovered after ultracentrifugation experiments or extracted from unstained gel slices after preparative electrophoresis (Aoki et al., 1979) were used to determine the nature of the major components of the purified enzymes. Samples $\left(0.5\right.$ to $0.65 \mathrm{mg}^{2}$ protein $\left.\mathrm{ml}^{-1}\right)$ were hydrolysed as described by Notario et al. (1976). The hydrolysates were filtered through a column of Dowex $50 \mathrm{~W}$ $(2 \times 18 \mathrm{~cm})$. Neutral sugars were eluted with water and amino acids with $0.5 \mathrm{M}$-ammonia. Both eluates were concentrated under vacuum and analysed by paper chromatography.

Paper chromatography. Descending paper chromatography of either enzyme hydrolysates (neutral sugar fraction) or the products of the enzyme action was carried out as described by Notario et al. (1976). Two-dimensional paper chromatography was used for the qualitative determination of amino acids. Chromatograms were developed on Whatman no. 4 paper $(50 \times 50 \mathrm{~cm})$ using $n$-butanol/acetic acid/water (12:3:5, by vol.) in the first direction, and phenol/water/ammonia (8:1:1, by vol.) in the second. Spots were developed by spraying the air-dried paper with a solution of ninhydrin in acetone $(2 \%, w / v)$, and heating the paper for $2 \mathrm{~min}$ at 100 to $105^{\circ} \mathrm{C}$.

Isolation and characterization of autolysis products. Total lipids were extracted by shaking the autolysates at room temperature with equal volumes of chloroform/methanol $(2: 1$, by vol.) for $5 \mathrm{~h}$. Lipids were washed as described by Folch et al. (1957) and determined gravimetrically. Polysaccharides were isolated by precipitation in the cold with 2 volumes of absolute ethanol or acetone; the precipitates were collected by centrifugation, resuspended in water and re-precipitated; the process was repeated three or four times and the final aqueous solution was dialysed overnight at $4{ }^{\circ} \mathrm{C}$ against 10 volumes of water and then freeze-dried. Samples of that material were hydrolysed with either $3 \mathrm{M}-\mathrm{HCl}$ or $7.5 \mathrm{M}^{-} \mathrm{H}_{2} \mathrm{SO}_{4}$ for $8 \mathrm{~h}$ at $100^{\circ} \mathrm{C}$. The monosaccharides and small oligosaccharides present either in the autolysates themselves or in the polysaccharide hydrolysates were characterized by descending paper chromatography. Total carbohydrate was determined according to Herbert $\boldsymbol{e t}$ al. (1971) with anthrone. Protein bound to $\beta$-glucans was detected and isolated as described by Dickerson \& Baker (1979). Total protein was determined by Lowry's method using bovine serum albumin as reference. 
Treatment of purified cell walls with SH-reactive agents, lytic enzymes and sonication. Purified cell walls were treated with SH-reactive agents and exogenous lytic enzymes as described by Gale et al. $(1975,1980)$ for whole organisms. For ultrasonic treatments, purified cell walls were suspended in water $(10 \mathrm{mg}$ dry wt ml-1) and $1 \mathrm{ml}$ fractions were treated at $4{ }^{\circ} \mathrm{C}$ for up to $15 \mathrm{~min}$ in a Dawe Soni-Cleaner (type 6441A). After sonication the fractions were kept in ice for $10 \mathrm{~min}$ and then centrifuged at $2000 \mathrm{~g}$ for $5 \mathrm{~min}$. The supernatants were saved and used to determine the nature of the released material and to measure $(1 \rightarrow 3)-\beta$-D-glucanase activity. The treated cell walls were resuspended in $1 \mathrm{ml} 50 \mathrm{~mm}$-sodium acetate buffer $\mathrm{pH} 5.5$ and used to determine the bound $\beta$-glucanase activities.

Effect of diethyl pyrocarbonate on $(1 \rightarrow 3)$ - $\beta$-D-glucanase activity. Conditions for treatment with diethyl pyrocarbonate were based on those described by Kritzman et al. (1978). Diethyl pyrocarbonate (final concentration $0.5 \mathrm{M}$ ) was added to suspensions of purified cell walls $\left(10 \mathrm{mg}\right.$ dry $\mathrm{wt} \mathrm{ml}^{-1}$ ) or to cell wall autolysates. Treatments were carried out under nitrogen at $4{ }^{\circ} \mathrm{C}$ for up to $5 \mathrm{~min}$. Cell walls were collected by centrifugation, washed three times with $50 \mathrm{mM}$-sodium acetate buffer $\mathrm{pH} 5 \cdot 5$, and assayed for residual $\beta$-glucanase activities.

Enzyme assays. Unless otherwise indicated, standard reaction mixtures contained $0.1 \mathrm{ml}$ of enzyme preparation plus $0.4 \mathrm{ml}$ of either laminarin or $p$-nitrophenyl- $\beta$-D-glucoside (pNPG) prepared in 50 mM-sodium acetate buffer $\mathrm{pH} 5.5$ to a final concentration in the assay of $0.25 \%(\mathrm{w} / \mathrm{v})$. Under these conditions, product formation was proportional to the time of incubation for up to $40 \mathrm{~min}$ when the protein concentration ranged between 0.1 and $5 \mathrm{mg} \mathrm{ml}^{-1}$. After incubation at $37^{\circ} \mathrm{C}$ for $20 \mathrm{~min}$, standard reactions were stopped by heating to $100^{\circ} \mathrm{C}$ for 3 to $5 \mathrm{~min}$ (assays on laminarin) or by adding $4.5 \mathrm{ml} 0.37 \mathrm{M}-\mathrm{Na}_{2} \mathrm{CO}_{3}$ (assays on pNPG). When crude extracts were used, the reactions were stopped by addition of $0.5 \mathrm{ml} 5 \%(\mathrm{w} / \mathrm{v}) \mathrm{ZnSO}_{4}$ plus $0.5 \mathrm{ml} 0.3 \mathrm{M}-\mathrm{Ba}(\mathrm{OH})_{2}$, the reaction products being determined in the supernatants obtained after centrifugation at $2000 \mathrm{~g}$ for 5 min. The activity on laminarin was estimated by measuring the released glucose or equivalent reducing sugar according to Bruss \& Black (1978) and Nelson (1944), respectively. Glucose and reducing sugars in the presence of SH-agents were estimated as described by Davies \& Wayman (1973). The activity on pNPG was determined by measuring the $A_{420}$ of the released $p$-nitrophenol. One unit of activity was defined as the amount of enzyme which liberated 1 nmol product $\min ^{-1}$.

Materials. Laminarin, methylglucose, $p$-nitrophenyl derivatives, cross-linked albumin, Triton X-100, cetyltrimethylammonium bromide (CTAB) and guanidine hydrochloride were purchased from Sigma. Sodium dodecyl sulphate (SDS), urea and lithium chloride were purchased from BDH. Beef liver catalase, rabbit muscle aldolase and Escherichia coli $\beta$-galactosidase were obtained from Boehringer. Pseudonigeran was prepared from $A$. niger as described by Hasegawa et al. (1969). Phosphomannan from Hansenula holstii, soluble laminarin (degree of polymerization 10-12) and defatted pachyman from Poria cocos were gifts from Dr T. G. Villa of Salamanca University, Spain. The sources of all other substrates and enzymes have been described elsewhere (Notario et al., 1976; Villa et al., 1976; Gale et al., 1980).

\section{RESULTS}

\section{Enzyme production and location: variation with growth}

After treatment with mild acid solutions, which inactivates the extracytoplasmically located enzymes (Arnold, 1972), there was a significant decrease in the activities on pNPG and laminarin, whereas neither cell viability nor $\alpha$-glucosidase, a cytoplasmic enzyme, were affected at any stage of growth. In AME sensitive (exponentially growing) organisms about $9 \%$ of the activity on pNPG and $17 \%$ of that on laminarin were not located in the cytoplasm. Those percentages increased up to 45 and $67 \%$, respectively, in organisms highly resistant to AME (cultures grown for $168 \mathrm{~h}$ ). Assuming that organisms grown for different periods were equally susceptible to the acid treatment, the proportion of both activities located extracytoplasmically increased with the age of the cultures.

Very low levels of the activities towards laminarin and pNPG were found in either cell-wall autolysates (Fig. 1a) or culture fluids (Fig. 1b) of AME-sensitive organisms (cultures grown for $7 \mathrm{~h}$ ). The two activities increased continuously in both locations after the cessation of growth, reaching maximum levels during the late stationary phase (Fig. 1a,b), when the organisms show high phenotypic resistance to AME.

The activities towards laminarin and pNPG detected in cell-wall autolysates of organisms from the stationary phase of growth were higher than those found when the same cell walls were used directly (without autolysis) as enzyme source in the assays (compare the values for 


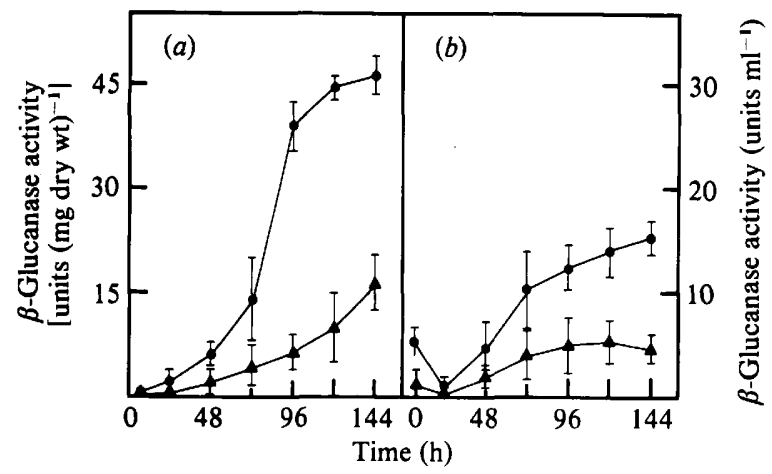

Fig. 1. Total activities on laminarin $(O)$ and $p$-nitrophenyl- $\beta$-D-glucoside $(\boldsymbol{\Delta})$ associated with the cell walls $(a)$ or present in the culture fluids $(b)$ of Candida albicans at different phases of growth. Wall autolysates and culture fluid extracts were prepared as described in Methods. The data for the wall-associated activities correspond to the sum of residual and solubilized activities. Results are the means of three determinations; the bars indicate the range of variation.

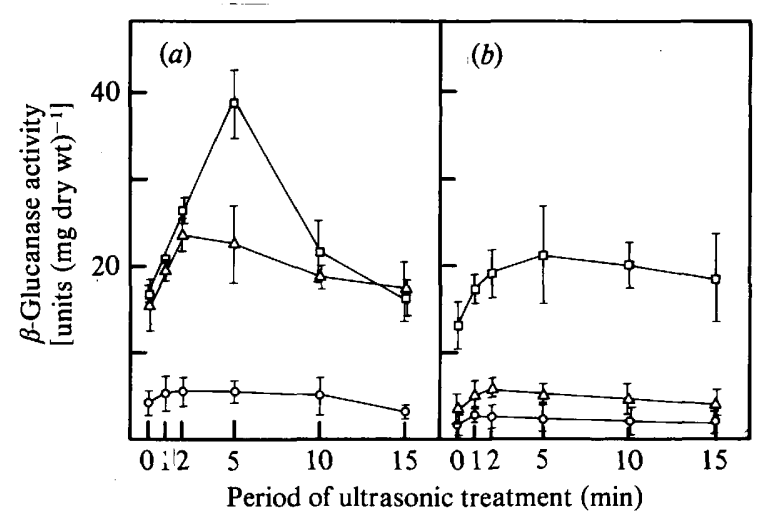

Fig. 2. Stimulation of wall-associated activities on laminarin ( $a$ ) and $p$-nitrophenyl- $\beta$-D-glucoside $(b)$ by ultrasonic treatment. The walls were purified from organisms grown for $7(O), 96(\triangle)$ and $168 \mathrm{~h}(\square)$. The points represent the means of three replicates, and the bars indicate the range of variation.

$96 \mathrm{~h}$ in Fig. $1 a$ and the initial ones for the same culture period in Fig. 2). These results suggested that the two enzymes were present on the cell walls at least partially in an inactive form which was activated upon autolysis.

\section{Enzyme attachment to the cell walls}

Ultrasonic treatment of intact cell walls. Small amounts of protein and carbohydrate (less than $2 \% \mathrm{w} / \mathrm{w}$ at the maximum) were released when cell walls from organisms cultured for different periods were sonicated for up to $15 \mathrm{~min}$. Neither the activity on laminarin nor that on pNPG were solubilized by such treatment. However, when sonicated cell walls from organisms from the stationary phase of growth (grown for 96 and 168 h, Fig. 2) were used as enzyme source in standard assays, the two activities were higher than those present in untreated controls. The effect was more marked for the activity on laminarin than for that on pNPG. No significant change in the amount of either activity was found upon sonication of cell walls from exponentially growing organisms (cultures grown for $7 \mathrm{~h}$, Fig. 2).

Cell wall autolysis. Protein, carbohydrate and $\beta$-glucanase activities were released from the cell walls when these were incubated under autolytic conditions. Table 1 shows the results of 


\section{Table 1. Autolysis of purified cell walls of Candida albicans}

The values presented are for cell walls from organisms grown for $168 \mathrm{~h}$ (AME-resistant) which were autolysed without continuous dialysis. Samples were taken at the times shown and centrifuged at $5000 \mathrm{~g}$ for $10 \mathrm{~min}$, and total carbohydrate, protein and enzyme activities in the supernatants were measured. The pellets were washed twice with $50 \mathrm{~mm}$-acetate buffer $\mathrm{pH} 5 \cdot 5$, and used to determine $\beta$-glucanase activities on laminarin and $p$-nitrophenyl- $\beta$-D-glucoside (pNPG), which are expressed as units (mg dry wt) $)^{-1}$.

\begin{tabular}{|c|c|c|c|c|c|c|}
\hline \multirow{2}{*}{$\begin{array}{l}\text { Autolysis } \\
\text { period } \\
\text { (h) }\end{array}$} & \multirow{2}{*}{$\begin{array}{c}\text { Released } \\
\text { carbohydrate } \\
{\left[\mu \mathrm{g}(\mathrm{mg} \text { dry } \mathrm{wt})^{-1}\right]}\end{array}$} & \multirow{2}{*}{$\begin{array}{c}\text { Released } \\
\text { protein } \\
{\left[\mu \mathrm{g}(\mathrm{mg} \text { dry } \mathrm{wt})^{-1}\right]}\end{array}$} & \multicolumn{2}{|c|}{ Solubilized activity on: } & \multicolumn{2}{|c|}{ Residual activity on: } \\
\hline & & & Laminarin & pNPG & Laminarin & pNPG \\
\hline 0 & - & 一 & - & - & $8 \cdot 4$ & 1.9 \\
\hline 2 & 135 & 9 & $10 \cdot 3$ & $4 \cdot 7$ & 47.5 & 12.9 \\
\hline 6 & 302 & 20 & $19 \cdot 1$ & 7.2 & $27 \cdot 3$ & 6.8 \\
\hline 10 & 366 & 31 & $22 \cdot 7$ & $8 \cdot 1$ & $19 \cdot 4$ & $5 \cdot 1$ \\
\hline 16 & 387 & 43 & $23 \cdot 7$ & $9 \cdot 3$ & $18 \cdot 7$ & $4 \cdot 3$ \\
\hline 20 & 403 & 51 & $25 \cdot 1$ & 8.4 & 17.9 & $3 \cdot 0$ \\
\hline 36 & 416 & 56 & $26 \cdot 4$ & 9.0 & $17 \cdot 3$ & 3.4 \\
\hline 48 & 408 & 55 & 27.8 & 9.0 & $16 \cdot 7$ & $3 \cdot 1$ \\
\hline
\end{tabular}

Table 2. Effect of solubilizing agents on wall autolysis

The autolysis buffer was supplemented with the agents shown and autolysis was carried out without continuous dialysis, under otherwise standard conditions (see Methods for details). The values given represent the total enzyme activities released after $48 \mathrm{~h}$ incubation, corrected for any inhibition caused by these agents on solubilized enzymes in vitro. They are expressed as percentages of the control activity, which was $25.6 \pm 1.2$ units (mg dry wt) $)^{-1}$ on laminarin and $9.2 \pm 3.5$ on pNPG. The range of variation in three replicates is indicated.

\begin{tabular}{lccc}
\multirow{2}{*}{ Addition } & & \multicolumn{2}{c}{ Released activity (\%) on: } \\
\cline { 2 - 3 } None & Concn & Laminarin & pNPG \\
$\mathrm{KCl}$ & - & 100 & 100 \\
& $1 \mathrm{M}$ & $107 \pm 2$ & $142 \pm 3$ \\
$\mathrm{LiCl}$ & $2 \mathrm{M}$ & $163 \pm 4$ & $174 \pm 2$ \\
& $2 \mathrm{M}$ & $93 \pm 5$ & $117 \pm 2$ \\
Guanidine.HCl & $4 \mathrm{M}$ & $122 \pm 1$ & $91 \pm 6$ \\
& $4 \mathrm{M}$ & $128 \pm 2$ & $146 \pm 3$ \\
Urea & $8 \mathrm{M}$ & $78 \pm 3$ & $97 \pm 2$ \\
& $4 \mathrm{M}$ & $109 \pm 12$ & $110 \pm 4$ \\
Triton X-100 & $8 \mathrm{M}$ & $76 \pm 9$ & $82 \pm 8$ \\
& $0.5 \%(\mathrm{w} / \mathrm{v})$ & $109 \pm 2$ & $107 \pm 6$ \\
CTAB & $1.0 \%(\mathrm{w} / \mathrm{v})$ & $114 \pm 11$ & $135 \pm 9$ \\
& $0.1 \%(\mathrm{w} / \mathrm{v})$ & $97 \pm 4$ & $95 \pm 2$ \\
SDS & $0.5 \%(\mathrm{w} / \mathrm{v})$ & $113 \pm 4$ & $172 \pm 7$ \\
& $1 \%(\mathrm{w} / \mathrm{v})$ & $174 \pm 5$ & $179 \pm 6$ \\
& $2 \%(\mathrm{w} / \mathrm{v})$ & $256 \pm 8$ & $209 \pm 9$
\end{tabular}

a typical experiment with cell walls from organisms in the stationary phase of growth. After $2 \mathrm{~h}$ incubation there was a significant stimulation of the activities on laminarin and pNPG, but the greater part remained attached to the walls. The extent of such initial stimulation was less marked when cell walls from exponentially growing organisms were used. Apart from this, qualitatively similar results were obtained with cell walls from organisms harvested at different stages of growth. After a rapid detachment over the first 6 to $8 \mathrm{~h}$, the rate of release declined and a steady level was reached after about $20 \mathrm{~h}$. No further release was attained by extending the incubation to $48 \mathrm{~h}$, when only 55 to $66 \%$ of the $\beta$-glucanase activities had been liberated. An unexplained loss of total enzyme activity (soluble plus bound) occurred during autolysis. This phenomenon was repeatedly observed and was less marked when autolysis was performed into dialysis sacs. Similar results were obtained when inhibitors of proteolytic 


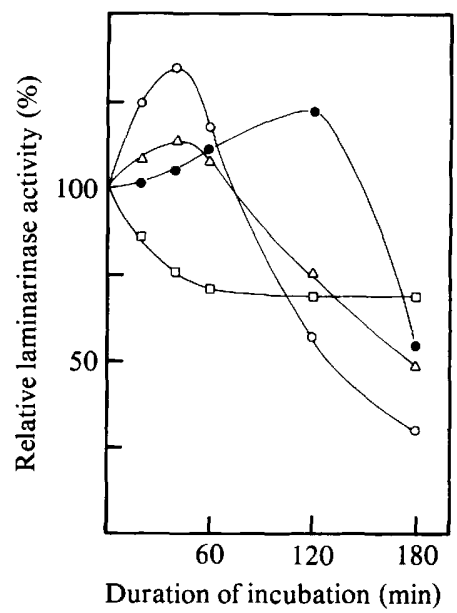

Fig. 3. Effect of enzyme treatment on the activity against laminarin bound to cell walls purified from organisms grown for $168 \mathrm{~h}$. The cell walls were incubated with lipase $(O)$, chitinase $(\triangle)$ or trypsin $(\square)$ as described by Gale et al. (1980). The partially digested cell walls were tested for activity on laminarin as described in the text. Untreated cell walls, showing an initial activity (taken as $100 \%$ ) on laminarin of $18.7 \pm 3.3$ units (mg dry $w t)^{-1}$, were used as control $(O)$.

enzymes (phenylmethylsulphonyl fluoride, pepstatin) were added from the beginning of the autolysis.

After $4 \mathrm{~h}$ autolysis, laminaritetraose and laminaripentaose were the main soluble carbohydrates released from the walls. Minor amounts of free glucose, laminaribiose and laminaritriose, and traces of mannose and glucosamine, were also detected. After $48 \mathrm{~h}$ incubation glucose was the major autolysis product. Laminaritetraose, mannose, glucosamine and high molecular weight compounds (remaining at the origin of the chromatograms) were also found. Lipid (up to $4.5 \%$ on a dry weight basis) and protein materials released from the beginning of autolysis have not been characterized.

The extent of the autolytic release of $\beta$-glucanase activities from the walls of organisms in the stationary phase of growth could be modified in various ways. Table 2 summarizes the results obtained by supplementing the autolysis buffer with solubilizing agents at different concentrations. Almost all of these agents increased the release of both glucanase activities to some extent, but $2-\mathrm{M}-\mathrm{KCl}$ and 1 to $2 \%(\mathrm{w} / \mathrm{v})$ SDS were the most effective substances. Diethyl pyrocarbonate, a known $(1 \rightarrow 3)-\beta$-D-glucanase inhibitor (Kritzman et al., 1978) completely prevented autolysis. When the cell walls were pretreated with either 5 min sonication or $0.2 \mathrm{M}-\beta$-mercaptoethanol for $10 \mathrm{~min}$ at $37^{\circ} \mathrm{C}$ there was some increase in the extent of enzyme release, which ranged from 62 to $74 \%$ and 68 to $74 \%$, respectively, in three separate experiments.

Treatment of purified cell walls with exogenous lytic enzymes. The incubation of cell walls purified from organisms from the stationary phase of growth with exogenous enzymes promoted certain changes in the detectable amounts of endogenous $\beta$-glucanase activities (Fig. 3). Lipase gave a $30 \%$ stimulation in about $40 \mathrm{~min}$; chitinase had little effect and trypsin was inhibitory. The three exogenous enzymes inhibited the endogenous $\beta$-glucanases after treatment for longer than $60 \mathrm{~min}$. Incubation of cell walls with lipase for $30 \mathrm{~min}$ at $37^{\circ} \mathrm{C}$ prior to autolysis increased the autolytic release of $\beta$-glucanase by 82,84 and $91 \%$ after $48 \mathrm{~h}$ autolysis in three independent experiments.

Enzyme binding to $\beta$-glucans. Cell walls purified from organisms from the stationary phase of growth were autolysed for $3 \mathrm{~h}$. Two major polysaccharides were isolated from the autolysates by filtration through a column of Bio-gel P-100. Descending paper 
chromatography showed glucose and small amounts of mannose as the only neutral sugars present in hydrolysates of the isolated polysaccharides. Only one of the $\beta$-glucans underwent limited autolysis when incubated under appropriate conditions, suggesting that $\beta$-glucanase activity was associated with it. Laminaritetraose was the main product of autolysis suggesting that the associated enzyme was an endo-glucanase. Attempts to separate the enzymically active protein from the carbohydrate as described by Dickerson \& Baker (1979) were unsuccessful.

\section{Enzyme purification}

The highest activities towards laminarin and pNPG produced by AME-sensitive and AME-resistant organisms were reached after 7 and $96 \mathrm{~h}$ of growth, respectively. Such cultures were therefore chosen to prepare cell-free extracts, cell-wall autolysates and culture fluids to be used as enzyme sources for purification purposes. Though pNPG is a model substrate for $\beta$-glucosidase (EC 3.2.1.21), it is also readily hydrolysed by exo- but not endo-( $1 \rightarrow 3)-\beta$-D-glucanases. Laminarin can be hydrolysed by both types of glucanases. Therefore both laminarin and pNPG were used as substrates throughout the purification process to distinguish between total $\beta$-glucanase (endo- plus exo-activity on laminarin) and exo- $\beta$-glucanase (activity on pNPG).

Table 3 shows the purification steps followed and the results obtained with the $\beta$-glucanase activities present in cell-free extracts from organisms grown for $96 \mathrm{~h}$. Two different proteins (I and II) were demonstrated and purified to homogeneity. The degree of purification ranged from 177 - to 990 -fold, depending on the origin of the enzymes.

\section{Enzyme characterization}

Each of the two enzymes (I and II) behaved in the same way throughout the purification process and exhibited almost identical properties whether purified from cell-free extracts, cell-wall autolysates or culture fluids of AME-sensitive or phenotypically resistant organisms. These findings suggested that there are only two distinct $\beta$-glucanases present. Accordingly, in this section the enzymes will be referred to as forms I and II, regardless of their origin.

Enzyme composition. Both carbohydrate and enzyme activity towards both laminarin and pNPG were invariably found in the same fractions after gel filtration, electrophoresis, isoelectric focusing and ultracentrifugation experiments. Acid hydrolysates of enzyme I contained $41 \%$ carbohydrate while those of enzyme II had only $12 \%$. Paper chromatography showed that glucose and mannose were present in both hydrolysates, and it was estimated (by subtracting the amount of free glucose from total carbohydrate values) that the ratio mannose/glucose was 5.2 for enzyme I and 0.96 for enzyme II. This difference may account for the different interactions of enzymes I and II with Concanavalin A-Sepharose 4B: enzyme I bound to such gel, while enzyme II did not. Glutamic acid, aspartic acid, serine, alanine and threonine, in that order, were found as the major components of the peptide moieties of both enzymes.

Enzyme properties.

Isoelectric focusing. Both enzymes focused as single peaks and the pI values were estimated to be 4.5 for enzyme I and 3.6 for enzyme II. These results show that both enzymes have net negative charges, in agreement with their high contents of acidic amino acids and the observation that they were adsorbed on to DEAE-Sephadex A-50.

Molecular weight. Gel filtration through Bio-gel P-200 suggested molecular weights of 145000 and 46000 for enzymes I and II, in agreement with those determined from SDS-polyacrylamide electrophoresis: 148000 for enzyme I and 48000 for enzyme II. Ultracentrifugation experiments gave somewhat higher values: $157000\left(s_{20, w} 7 \cdot 52 S\right)$ for enzyme I and $53000\left(s_{20, w} 3 \cdot 64 S\right)$ for enzyme II. 


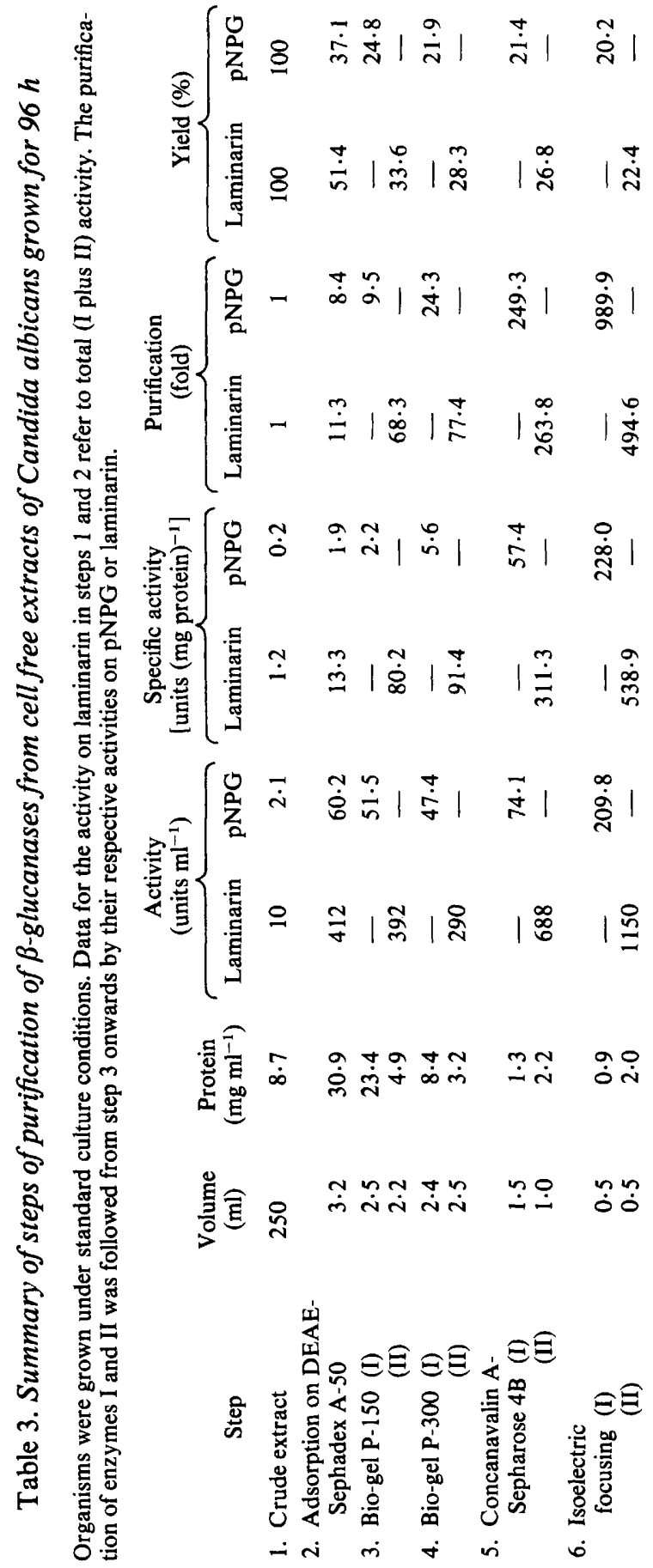




\title{
Table 4. Substrate specificity of the purified $\beta$-glucanases
}

\begin{abstract}
Assays were carried out for $1 \mathrm{~h}\left(10 \mathrm{~min}\right.$ for $K_{\mathrm{m}}$ determinations) at $37^{\circ} \mathrm{C}$. The standard substrate concentration was $0.25 \%(\mathrm{w} / \mathrm{v})$ in $50 \mathrm{mM}$-sodium acetate buffer $\mathrm{pH} 5 \cdot 5$. For $K_{\mathrm{m}}$ determinations the substrate concentration ranged from 0.08 to $30 \mathrm{mg} \mathrm{ml}^{-1}$. Purified enzymes were used except for pachyman (see footnote); 50 enzyme units were used in every case. To express $K_{\mathrm{m}}$ values on a molar basis the degree of polymerization of the substrate was estimated according to Reese \& Mandels (1963). + , Hydrolysis;,- , no hydrolysis; \pm , trace. $K_{m}$ values $(\mathrm{mM})$ are given in parentheses.
\end{abstract}

\begin{tabular}{lccc}
\multicolumn{1}{c}{ Substrate } & $\begin{array}{c}\text { Main linkage } \\
\text { type }\end{array}$ & $\overbrace{\text { Enzyme I }}$ & Enzyme II \\
Laminarin & $(1 \rightarrow 3)-\beta$ & $(1.02)$ & $(0.47)$ \\
Oxidized laminarin & $(1 \rightarrow 3)-\beta$ & - & $(0.17)$ \\
Soluble laminarin & $(1 \rightarrow 3)-\beta$ & $(0.46)$ & $(0.25)$ \\
Pachyman* & $(1 \rightarrow 3)-\beta$ & + & + \\
Yeast glucan & $(1 \rightarrow 3)-\beta$ & $+\dagger$ & $(0.08)$ \\
Pustulan & $(1 \rightarrow 6)-\beta$ & $(0.13)$ & $(0.47)$ \\
pNPG & - & $(2.65)$ & \pm
\end{tabular}

Neither enzyme had detectable activity on the following substrates: gentiobiose, yeast mannan, phosphomannan, nigeran, pseudonigeran, cellobiose and $p$-nitrophenyl derivatives other than pNPG.

* Enzymes used after purification to step 5 (Table 3).

+ Very long incubations were required to detect any significant activity and kinetic parameters could not be accurately determined.

Effect of $p H$ and temperature. The maximum rate of reaction for both enzymes was reached at $50{ }^{\circ} \mathrm{C}$. However, only $80 \%$ of the activity of enzyme I and $93 \%$ of that of enzyme II were recovered when standard assays were performed with enzyme samples which had been preincubated at $50^{\circ} \mathrm{C}$ for $15 \mathrm{~min}$. The optimum $\mathrm{pH}$ for both enzymes was $5 \cdot 5$, but they exhibited different profiles. While enzyme I was rapidly inactivated at $\mathrm{pH}$ values above 6.5 or below 5.0, enzyme II remained almost fully active within a broader $\mathrm{pH}$ range, retaining more than $90 \%$ of its catalytic activity at $\mathrm{pH}$ values from 4.6 to $7 \cdot 5$. Enzyme II was almost completely inactivated at or above $\mathrm{pH} \mathrm{8.0.} \mathrm{Similar} \mathrm{results} \mathrm{were} \mathrm{obtained} \mathrm{upon} \mathrm{storage} \mathrm{of} \mathrm{the}$ enzymes at different $\mathrm{pH}$ values. At $\mathrm{pH} 5.5$ both enzymes could be stored at 0 to $4{ }^{\circ} \mathrm{C}$ for at least 2 months without appreciable loss of activity.

Specificity and mode of action. Table 4 summarizes the substrate specificity of the purified enzymes and shows the $K_{\mathrm{m}}$ values for some of the substrates. Both enzymes appeared to be specific for $\beta$-linked substrates. However, there was an inhibitory effect when laminarin, oxidized laminarin or pustulan were used at concentrations above $15 \mathrm{mg} \mathrm{ml}^{-1}$. Such an effect was not found in assays using pNPG as substrate. Paper chromatography of reaction mixtures stopped at different times (up to $6 \mathrm{~h}$ ) showed glucose as the only product of the action of enzyme I on laminarin, soluble laminarin and pustulan. The products of enzyme II varied as a function of time. Laminaritetraose was the only initial product ( 10 min assays), but after $30 \mathrm{~min}$ reaction the amount of laminaritetraose decreased in parallel with the appearance of increasing amounts of glucose. After $6 \mathrm{~h}$, glucose was the only product released by enzyme II from all the substrates tested.

Each enzyme was able to liberate reducing sugars from cell walls purified from AME-sensitive organisms (cultures grown for $7 \mathrm{~h}$ ), and their effects were additive when used simultaneously. No significant differences were found when cell walls from AME-resistant organisms were used as substrate.

Effect of glucose analogues, $S H$-reactive agents and metal ions. Glucono- $\delta$-lactone non-competitively inhibited both enzymes I and II. The $K_{\mathrm{i}}$ values were $1.34 \mathrm{~mm}$ for enzyme I and $6.25 \mathrm{~mm}$ for enzyme II. Glucuronolactone and 2-deoxy-D-glucose had no effect on enzyme I, but enhanced the activity of enzyme II (by 3- and 6-fold, respectively, at a final concentration in the assay of $10 \mathrm{~mm}$ ). 
The activity on laminarin determined in organisms rendered permeable by toluene treatment (Notario et al., 1982), was also enhanced (by up to $47 \%$ ) by 2-deoxy-D-glucose within the range from 0.3 to $3 \mathrm{~mm}$. Under these same assay conditions $0.3 \mathrm{~mm}$-D-allose produced a $50 \%$ inhibition of the activity on laminarin, but the inhibition decreased at higher concentrations (22\% at $1 \mathrm{mM})$. 3-O-Methylglucose and 5-thioglucose had little effect within the range from 0.3 to $1 \mathrm{mM}$. At $3 \mathrm{~mm}, 3-O$-methylglucose enhanced the activity on laminarin by $66 \%$ while 5 -thioglucose inhibited it by $88 \%$.

Both purified enzymes were activated by $0.2 \mathrm{M}-\beta$-mercaptoethanol. The extent of activation was never higher than $25 \%$, whereas in crude extracts stimulations of about 100 to $200 \%$ could be attained (Notario et al., 1982). $N$-Ethylmaleimide ( $1 \mathrm{mM}$ ) inhibited the activity of both purified enzymes ( $29 \%$ for enzyme I and $12 \%$ for enzyme II) after 60 min treatment, but the extent of inhibition was much smaller than that found with crude extracts (Notario et al., 1982).

Enzymes I and II were inhibited by $\mathrm{Hg}^{2+}$. The estimated $K_{\mathrm{i}}$ values were $22 \mu \mathrm{M}$ for enzyme I and $0.36 \mathrm{mM}$ for enzyme II. Other metal ions such as $\mathrm{Ag}^{+}, \mathrm{K}^{+}, \mathrm{Ca}^{2+}, \mathrm{Mg}^{2+}, \mathrm{Ba}^{2+}, \mathrm{Zn}^{2+}$, $\mathrm{Co}^{2+}$ and $\mathrm{Al}^{3+}$ had no effect on the enzyme activities at concentrations up to $10 \mathrm{mM}$.

\section{DISCUSSION}

Notario et al. (1982) described the occurrence of a sharp decline in the cell-associated activities towards laminarin (80\% decrease) and pNPG (52\% decrease) simultaneously with the development of phenotypic resistance to AME in C. albicans, between 7 to $12 \mathrm{~h}$ of growth. Evidence was provided relating the metabolic state of the cell-wall $\beta$-glucan and the endogenous levels of $\beta$-glucanase activities to the onset and development of antibiotic resistance.

Differences in $\beta$-glucanase levels between AME-sensitive and resistant organisms may result from a number of causes: (1) the enzymes are exported to the culture medium; (2) the enzymes are destroyed intra- or extracellularly; (3) AME-sensitive and resistant organisms contain different enzyme forms; (4) the enzymes are the same in the two kinds of organisms but show different properties depending on the age of the cultures; (5) the enzymes accumulate in the organisms in an inactive state at the end of the active growth; and (6) combinations of the above.

The activities towards laminarin and pNPG present in culture fluids after 7 to $12 \mathrm{~h}$ of growth were too low (Fig. $1 b$ ) to account for the decrease in the cellular levels of $\beta$-glucanases. Moreover, during the same culture period the protease levels in both cell-free extracts and culture fluids of $C$. albicans were almost undetectable (results not shown). Therefore, it seems unlikely that either of the first two explanations is valid. The results described in this paper suggest that the third and fourth explanations (see above) should also be ruled out. The same two enzyme species (I and II) were present in all of the extracts prepared from AME-sensitive and resistant organisms, and exhibited similar properties regardless of the age of the cultures.

Though enzyme I was highly active against pNPG, its ability to hydrolyse oligo- and polysaccharides such as pachyman, yeast $(1 \rightarrow 3)$ - $\beta$-glucan and pustulan (Table 4$)$ suggest that its activity is closer to that of an exo- $(1 \rightarrow 3)-\beta$-D-glucanase such as the one described by Barras \& Stone (1969) than to a typical $\beta$-glucosidase. Enzyme II shows some peculiarities such as a broad $\mathrm{pH}$ range of activity, stimulation by glucuronolactone and 2-deoxy-D-glucose and mode of action, releasing laminaritetraose initially and degrading it to glucose on prolonged incubation. The mechanism may be interpreted in two ways: either (i) the enzyme has a mixed pattern of action - endolytic initially, and exolytic once the degree of polymerization of the substrate is low enough; or (ii) it is an endo-enzyme with action decreasing as the degree of polymerization of the substrate decreases. The fact that neither laminaritriose nor laminaribiose were detected at any stage of the reaction support the first 
interpretation. However, on the basis of its much higher rate of release of laminaritetraose than of glucose, enzyme II could be considered to be primarily an endo- $(1 \rightarrow 3)$ $\beta$-D-glucanase.

The fact that purified enzymes were much less susceptible to treatments with SH-agents, $\mathrm{pH}$ changes, etc., than crude extracts or whole organisms suggests that the effect of these treatments is mainly due to the release of the enzymes from their association with other cell components. In turn this suggests that an important factor in the development of AME resistance could be the variation in the state of the enzymes within the cells with the phase of growth ( 5 , see above).

Concerning their $\beta$-glucanase activities, the main difference between AME-sensitive and resistant organisms is that in the latter, activities towards laminarin and pNPG are preferentially located on the cell walls, and remain mainly in a latent state which can be only activated after autolysis (Fig. 1 $a$, Table 1) or other physical, chemical or enzymic treatment. A simple explanation for the association and subsequent inactivation of $\beta$-glucanases on the cell walls of AME-resistant organisms could be based on spatial restrictions imposed on the enzyme molecules by a densely packed polysaccharide network. However, since no activity was released even after $15 \mathrm{~min}$ sonication, it seems that the retention of the lytic enzymes must be due to their binding to cell wall components rather than to a physical entrapment of the molecules within the polysaccharide network. Nevertheless, relaxation of the packing of the wall materials facilitates the detection of both activities on laminarin and pNPG (Fig. 2) in AME-resistant organisms, possibly by increasing the enzyme-substrate accessibility.

Evidence is presented which indicates that $\beta$-glucanases are bound to cell wall components and their activities thereby controlled. The three major wall components (carbohydrate, lipid and protein) seem to be involved in such binding. Coupling to polysaccharides is suggested by the release of carbohydrate during autolysis of either purified cell walls or isolated $\beta$-glucans. What limits autolysis is not clear. It is not the accumulation of low molecular weight products since their removal by dialysis does not affect the final yield. The enzymes released by autolysis remain fully active since autolysates bring about degradation of laminarin or freshly prepared cell walls (preheated to destroy endogenous activities). Possibly the endogenous enzymes are unable to attack the residual material. The residual enzyme activity on the autolysed material might be accounted for by enzymes I and II binding to different parts of the walls.

Sietsma \& Wessels (1979) described covalent linkages between chitin and $\beta$-glucan in fungal cell walls. If similar linkages exist in the walls of $C$. albicans, the effects of chitinase on autolysis and on the $\beta$-glucanase activities of intact organisms (Notario et al., 1982) could be due to an indirect action on enzymes bound to those glucan-chitin complexes.

The involvement of lipids is suggested by the action of lipase on purified cell walls (Fig. 3) and autolysis, and by the effect of detergents on autolysis (Table 2). Polacheck \& Rosenberger (1978) suggested that lytic enzymes were trapped in lipid vesicles within the walls of fungi, being only released by the action of detergents. The addition of detergents to the autolysis mixtures would disrupt those vesicles, if they exist in $C$. albicans, and release higher amounts of activity than those expected from the results obtained with other solubilizing treatments. The action of SH-reactive agents suggests a role of protein interactions, either directly between $\beta$-glucanases and other proteins in the wall, or indirectly by modification of an impermeable structure maintained by disulphide bridges as proposed by Lampen (1968) and Kidby \& Davies (1970) for yeast invertase.

The elucidation of the nature of those different interactions between lytic enzymes and cell wall components requires further investigation, particularly into the chemical architecture of the yeast cell wall.

This work was partially supported by a Postdoctoral Research Fellowship to the author from the Ministerio de Universidades e Investigación, Spain. 


\section{REFERENCES}

AOKI, K., Kajiwara, S., Shinke, R. \& Nishira, H. (1979). Tannic acid staining and extraction of enzymes in polyacrylamide gel electrophoresis. Analytical Biochemistry 95, 575-578.

ARNOLD, W. N. (1972). The structure of the yeast cell wall. Solubilization of a marker enzyme, $\beta$-fructofuranosidase, by the autolytic enzyme system. Journal of Biological Chemistry 247, 1161-1169.

BARRAS, D. R. \& Stone, B. A. (1969). B-1,3-Glucan hydrolases from Euglena gracilis. I. The nature of the hydrolases. Biochimica et biophysica acta 191, 329-341.

Bruss, M. L. \& BLACK, A. L. (1978). Enzymatic microdetermination of glycogen. Analytical Biochemistry 84, 309-312.

Cortat, M., Matile, P. \& Wiemken, A. (1972). Isolation of glucanase-containing vesicles from budding yeasts. Archiv für Mikrobiologie 82, 189205.

Davies, R. \& Wayman, F. J. (1973). Estimation of glucose and invertase activity in presence of thiols. Analytical Biochemistry 55, 143-153.

Dickerson, A. G. \& BAKER, R. C. F. (1979). The binding of enzymes to fungal $\beta$-glucans. Journal of General Microbiology 112, 67-75.

FARKAs, V., Biely, P. \& Bauer, S. (1973). Extracellular $\beta$-glucanases of the yeast Saccharomyces cerevisiae. Biochimica et biophysica acta 321, 246-255.

Fleet, G. H. \& Phaff, H. J. (1974). Glucanases in Schizosaccharomyces. Isolation and properties of the cell wall-associated $\beta$ - $(1 \rightarrow 3)$-glucanases. Journal of Biological Chemistry 249, 1717-1728.

Folch, J., Lees, M. \& Sloane-Stanley, G. H. (1957). A simple method for the isolation and purification of total lipids from animal tissues. Journal of Biological Chemistry 226, 497-509.

GALE, E. F. (1974). The release of potassium ions from Candida albicans in the presence of polyene antibiotics. Journal of General Microbiology 80, 451-465.

Gale, E. F., Johnson, A. M., KerRidGe, D. \& KoH, T. Y. (1975). Factors affecting the changes in amphotericin sensitivity of Candida albicans during growth. Journal of General Microbiology 87, 20-36.

Gale, E. F., Ingram, J., KerRidge, D., Notario, V. \& WAYMAN, F. J. (1980). Reduction of amphotericin resistance in stationary phase cultures of Candida albicans by treatment with enzymes. Journal of General Microbiology 117, 383-391.

Hasegawa, S., Nordin, J. H. \& Kirkwood, S. (1969). Enzymes that hydrolyse fungal cell wall polysaccharides. I. Purification and properties of an endo- $\alpha$-D- $(1 \rightarrow 3)$-glucanase from Trichoderma viride. Journal of Biological Chemistry 244, 54605470.

Herbert, D., Phipps, P. J. \& Strange, R. E. (1971). Chemical analysis of microbial cells. Methods in Microbiology 5B, 209-344.

JoHNSON, B. F. (1968). Lysis of yeast cell walls induced by 2-deoxyglucose at their sites of glucan synthesis. Journal of Bacteriology 95, 1169-1172.

KIDBY, D. K. \& DAviEs, R. (1970). Thiol induced release of invertase from cell walls of Sac charomyces fragilis. Biochimica et biophysica acta 201, 261-266.

Kritzman, G., Chet, I. \& Henis, Y. (1978). Location of $\beta$ - $(1,3)$-glucanase in the mycelium of Sclerotium rolfsii. Journal of Bacteriology 134, 470-475.

LAMPEN, J. O. (1968). External enzymes of yeasts: their nature and formation. Antonie van Leeuwenhoek 34, 1-8.

Nelson, N. (1944). A photometric adaptation of the Somogyi method for the determination of glucose. Journal of Biological Chemistry 153, 375-380.

Notario, V., Villa, T. G. \& Villanueva, J. R. (1976). Purification of an exo- $\beta$-glucanase from cell-free extracts of Candida utilis. Biochemical Journal 159, 555-562.

Notario, V., Villa, T. G. \& Villanueva, J. R. (1979). Cell wall-associated $1,4-\beta$-D-xylanase in Cryptococcus albidus var. aerius: in situ characterization of the activity. Journal of General Microbiology 114, 415-422.

Notario, V., Gale, E. F., Kerridge, D. \& Wayman, F. J. (1982). Phenotypic resistance to amphotericin B in Candida albicans: relationship to glucan metabolism. Journal of General Microbiology 128, $761-777$.

Phaff, H. J. (1971). Structure and biosynthesis of the yeast cell envelope. In The Yeasts. Volume 2, Physiology and Biochemistry of Yeasts, pp. 135210. Edited by A. H. Rose \& J. S. Harrison. New York and London: Academic Press.

PolACheck, I. \& Rosenberger, R. F. (1978). Distribution of autolysins in hyphae of Aspergillus nidulans: evidence for a lipid-mediated attachment to hyphal walls. Journal of Bacteriology 135, 741-747.

RACUSEN, D. (1979). Glycoprotein detection in polyacrylamide gel with thymol and sulphuric acid. Analytical Biochemistry 99, 474-476.

Reese, E. T. \& Mandels, M. (1963). Enzymatic hydrolysis of $\beta$-glucans. In Proceedings of the Symposium on Advances in Enzymic Hydrolysis of Cellulose and Related Materials, pp. 197-234. Edited by E. T. Reese. New York: Pergamon Press.

Sietsma, J. H. \& Wessels, J. G. H. (1979). Evidence for covalent linkages between chitin and $\beta$-glucan in a fungal wall. Journal of General Microbiology 114, 99-108.

Villa, T. G., Notario, V., Benitez, T. \& Villanueva, J. R. (1976). Purification of an exo-1,3- $\beta$-glucanase from Candida utilis. Canadian Journal of Biochemistry 54, 927-934.

Villanueva, J. R. \& Gacto, M. (1973). Characterization of $\beta$ - $(1,3)$-glucanases of yeasts. Proceedings of the 3rd International Specialized Symposium on Yeast, 261-283.

Villanueva, J. R., Notario, V., Santos, T. \& Villa, T. G. (1976). $\beta$-Glucanases in nature. Biochemistry and function of $\beta$-glucanases in yeast. In Microbial and Plant Protoplasts, pp. 323-355. Edited by J. F. Peberdy, A. H. Rose, H. J. Rogers \& E. C. Cocking. London: Academic Press. 